\title{
EIGENVALUE INEQUALITIES RELATED TO THE ANDO-HIAI INEQUALITY
}

\section{Mohammad BAgher GHaEmi And Venus Kaleibary}

Abstract. In this paper, we show that if $f$ is a doubly concave function on $[0, \infty)$ and $0<s A \leqslant$ $B \leqslant t A$ for some scalars $0<s \leqslant t$ with $w=t / s$, then for every $k=1,2, \cdots, n$,

$$
\lambda_{k}(f(A) \sharp f(B)) \leqslant \frac{w^{\frac{1}{4}}+w^{-\frac{1}{4}}}{2} \lambda_{k}(f(A \sharp B)),
$$

where $A \sharp B=A^{\frac{1}{2}}\left(A^{-\frac{1}{2}} B A^{-\frac{1}{2}}\right)^{\frac{1}{2}} A^{\frac{1}{2}}$ is the symmetric geometric mean. As an application, we give some reverses of Ando-Hiai and Golden-Thompson type inequalities. These new reverse inequalities, improve some known results.

Mathematics subject classification (2010): 47A63, 47A64, 15A60.

Keywords and phrases: Doubly concave function, Ando-Hiai inequality, Golden-Thompson inequality, reverse inequality, geometric mean, generalized Kantorovich constant, unitarily invariant norm.

\section{REFERENCES}

[1] T. Ando, F. HiaI, Log-majorization and complementary Golden-Thompson type inequalities, Linear Algebra Appl. 197/198 (1994), 113-131.

[2] R. Bhatia, Matrix Analysis, Grad. Texts in Math., vol. 169, Springer-Verlag, 1997.

[3] J.-C. Bourin, Reverse inequality to Araki's inequality comparison of $A^{p} Z^{p} A^{p}$ and $(A Z A)^{p}$, Math. Inequal. Appl. 8 (2005), 373-378.

[4] J.-C. BouRIN, F. HiAI, Jensen and Minkowski inequalities for operator means and anti-norms, Linear Algeb Appl. 456 (2014), 22-53.

[5] J.-C. Bourin, Y. SEO, Reverse inequality to Golden-Thompson type inequalities: comparison of $e^{A+B}$ and $e^{A} e^{B}$, Linear Algebra Appl. 426 (2007), 312-316.

[6] J.-C. Bourin, E. Y. LeE, M. FujII, Y. SEO, A matrix reverse Holder inequality, Linear Algebra Appl. 431 (2009), 2154-2159.

[7] T. Furuta, J. MićIĆ, J. E. PeČArić, Y. SEO, Mond-Pečarić method in operator inequalities, Monographs in Inequalities 1, Element, Zagreb, 2005.

[8] M. B. GhaEmi, V. KALEIBARY, Some inequalities involving operator monotone functions and operator means, Math. Inequal. Appl. 19 (2016), 757-764.

[9] F. HiAI, D. Petz, The Golden-Thompson trace inequality is complemented, Linear Algebra Appl. 181 (1993), 153-185.

[10] R. NAKAмото, Y. Seo, A complement of the Ando-Hiai inequality and norm inequalities for the geometric mean, Nihonkai Math. J. 18 (2007), 43-50.

[11] Y. SEO, On a reverse of Ando-Hiai inequality, Banach J. Math. Anal. 4 (2010), 87-91.

[12] Y. SEO, Reverses of the Golden-Thompson type inequalities due to Ando-Hiai-Petz, Banach J. Math. Anal. 2 (2008), 140-149. 